OPEN ACCESS

Edited by:

Panteleimon Giannakopoulos, Université de Genève, Switzerland

Reviewed by: KIymet Kübra Yurt,

Kastamonu University, Turkey Nafisa M. Jadavii, Midwestern University, United States

*Correspondence:

Puja Agarwal puja_agarwal@rush.edu

${ }^{\dagger}$ Deceased

Specialty section: This article was submitted to Health,

a section of the journal

Frontiers in Human Neuroscience

Received: 28 April 2020

Accepted: 06 August 2020

Published: 03 September 2020

Citation:

Agarwal P, Morris MC and Barnes LL (2020) Racial Differences in Dietary Relations to Cognitive Decline and Alzheimer's Disease Risk:

Do We Know Enough?

Front. Hum. Neurosci. 14:359. doi: 10.3389/fnhum.2020.00359

\section{Racial Differences in Dietary Relations to Cognitive Decline and Alzheimer's Disease Risk: Do We Know Enough?}

\author{
Puja Agarwal ${ }^{1 *}$, Martha C. Morris ${ }^{1 \dagger}$ and Lisa L. Barnes ${ }^{2,3}$ \\ ${ }^{1}$ Department of Internal Medicine, Rush Institute for Healthy Aging, Rush University Medical Center, Chicago, IL, \\ United States, ${ }^{2}$ Rush Alzheimer's Disease Center, Rush University Medical Center, Chicago, IL, United States, ${ }^{3}$ Department \\ of Neurological Sciences, Rush University Medical Center, Chicago, IL, United States
}

The elderly population in the US is increasing and projected to be $44 \%$ minority by 2060. African Americans and Hispanics are at increased risk of cognitive impairment and Alzheimer's disease compared to non-Hispanic whites. These conditions are associated with many other adverse health outcomes, lower quality of life, and substantial economic burden. In the past few decades, diet has been identified as an important modifiable risk factor for cognitive decline and Alzheimer's disease. Some studies report poor diet quality among African American and Hispanic older adult populations compared to their white counterparts. We have a limited understanding of how diet affects brain health in different racial-ethnic groups. One primary reason for our lack of knowledge is that most cohort studies are of majority non-Hispanic white participants. Moreover, those that do include minority participants do not publish their findings stratified by racial-ethnic groups, and likely have a less accurate measurement of dietary intake among minority groups. In this review, we summarize the current, albeit limited, literature on racial/ethnic differences in dietary relations to dementia outcomes. We will also discuss methodological issues in conducting nutrition studies in diverse cultures, and suggestions for future research directions. Overcoming the gaps will make it possible to make dietary recommendations for Alzheimer's prevention that are more relevant for different racial/ethnic groups and set us on a faster track to reduce health disparities.

\section{Keywords: diet, nutrition, cognition, health disparities, race}

\section{INTRODUCTION}

Currently, around 5.7 million Americans have Alzheimer's dementia, and with a growing aging population, the number is projected to increase to 13.8 million by 2050 (Hebert et al., 2013; Alzheimer's Association, 2018). The US aging population is also expected to become more racially and ethnically diverse in the coming years, so that by the year 2060, it will be approximately $44 \%$ minority (Colby and Ortman, 2014). One systematic review of multi-ethnic cohort studies concluded that dementia incidence rates are higher in African Americans and Hispanics compared to non-Hispanic Whites (Mehta and Yeo, 2017). Some have argued that these observed disparities are due to a multitude of related factors, including increased prevalence of cardiovascular conditions, lower education and socioeconomic status, barriers to health care, and certain lifestyle 
factors (Judd et al., 2013; Diaz-Venegas et al., 2016; Howard et al., 2018; Weuve et al., 2018). With limited treatments to reverse memory loss or dementia, the identification of modifiable risk factors are of great public health interest. Diet has emerged as a modifiable factor that affects cardiovascularrelated conditions but also may have independent effects on the development of dementia. A large body of literature has found that healthy dietary patterns, including the Mediterranean (Scarmeas et al., 2009; Tangney et al., 2011; Koyama et al., 2015; Morris et al., 2015b; Bhushan et al., 2018), DASH (Dietary approach to Reduce Hypertension) (Tangney et al., 2014; Morris et al., 2015b) and MIND (Mediterranean-Dash Intervention for Neurodegenerative Diseases) diets (Morris et al., 2015b,c; Berendsen et al., 2018), and specific foods [e.g., berries (Devore et al., 2012; Agarwal et al., 2019), vegetables (Morris et al., 2006, 2018; Ye et al., 2013a), fish (Morris et al., 2003; Samieri et al., 2018)] and nutrients [vitamin E (Morris et al., 2002a; Beydoun et al., 2015), flavonoids (Devore et al., 2012; Holland et al., 2020), B vitamins (Morris et al., 2005), unsaturated fats (Morris et al., 2004)] are associated with slower cognitive decline and/or reduced risk of dementia. However, the generalizability of these findings to individuals of different race and ethnic backgrounds is not well characterized. We know that diet quality varies by race and ethnicity in the U.S., but differences also occur by socioeconomic status, the region of the country, and urban/rural settings (Aggarwal et al., 2012; Hiza et al., 2013; McInerney et al., 2016; Bloom et al., 2017; Lee-Kwan et al., 2017). Racial/ethnic disparities in dementia may be due, in part, to dietary intakes of the nutrients and foods found to be important to brain health. This was reported to be the case for higher incidence rates of stroke and hypertension among African Americans compared to whites, which were partially explained by higher consumption of a Southern westernized diet pattern among African Americans (Judd et al., 2013; Howard et al., 2018). Unfortunately, in our current state of knowledge, there is limited data to investigate to what extent diet may account for these disparities in dementia. In this review, we will characterize social and biological differences by race and ethnicity that influence diet quality and nutritional metabolism, describe the existing multi-racial/ethnic studies of diet and dementia, and identify the methodological challenges and future directions in closing the gap in this field of scientific inquiry. The existing studies on the association between dietary patterns/food groups/nutrients and cognitive decline/Alzheimer's dementia risk from the longitudinal cohorts of US adults that included multi-racial/ethnic groups with more than $20 \%$ minority population are discussed in this review.

\section{RACIAL/ETHNIC DIFFERENCES IN HEALTH}

Various social and demographic factors that have been studied for health disparities in Alzheimer's dementia include educational attainment (Weuve et al., 2018), bilingualism (Lamar et al., 2019), neighborhood greenness (Brown et al., 2018), and stressful life events (Zuelsdorff et al., 2020). Similar social and economic aspects may also affect the diet quality by race, including education and income (Raffensperger et al., 2010), health literacy (Kuczmarski et al., 2016), food prices and diet costs (Townsend et al., 2009) and neighborhood grocery store availability (Powell et al., 2007; Bower et al., 2014). Healthy Aging in Neighborhoods of Diversity across the Life Span (HANDLS) study reported lower nutrient-based diet quality among African Americans compared to whites and found health literacy and education as important predictors of diet quality in this urban population (Raffensperger et al., 2010; Kuczmarski et al., 2016). Similarly, African Americans in the Jackson Heart Study reported fastfood clusters (including fast foods, salty snacks, non-diet soft drinks, and meat), as the most common dietary pattern in the study population and was found to be associated with significantly lower levels of plasma carotenoids and alpha tocopherols (Talegawkar et al., 2008). Considering that different social, economic, and demographic factors may influence both diet quality and cognition, examining racial differences in the association of diet with Alzheimer's dementia and/or cognitive decline, may help us explain, at least in part, health disparities in Alzheimer's dementia and related disorders.

Although race is socially constructed with little to no basis in biology, there are non-observable differences in nutritional metabolism based on such factors as skin color and body composition (Hall et al., 2010; Bhupathiraju et al., 2011). For example, ultraviolet rays are absorbed by the skin at different rates depending on the level of melanin or pigment in the skin. Racial groups with darker skin pigment require greater sun exposure than lighter-skinned groups to synthesize the same amount of vitamin D (Hall et al., 2010; Gallagher et al., 2013). Differences among racial/ethnic groups in fat and lean body mass can affect the storage and metabolism of a number of vitamins and minerals (Morton et al., 2003; Lear et al., 2009; Travison et al., 2011; Santoro et al., 2018). In the feeding trials, African Americans reported higher, postprandial triglycerides (Goff et al., 2016) and subnormal ghrelin (a gut-brain peptide to signal hunger) suppression (Brownley et al., 2004) compared to Whites. Independent of obesity, body fat distribution, and behavioral factors, African Americans but not Hispanics have high insulin resistance compared to non-Hispanic Whites (Haffner et al., 1996). Genetic variations can also affect susceptibility to DNA damage and DNA repair. For example, African Americans are reported to have lower serum levels of antioxidant nutrients in comparison to whites, yet surprisingly have less oxidative damage to DNA (Huang et al., 2000; Watters et al., 2007). Similarly, a longitudinal analysis indicated higher parathyroid hormones increased diabetes risk only in Whites and not in African Americans (Reis et al., 2016). The growing evidence of differences in nutrition metabolism by race and ethnicity is a compelling reason for their scientific exploration in the dementia field.

\section{MULTI-RACIAL/ETHNIC COHORT STUDIES ON DIET AND DEMENTIA}

A large body of literature over the past two decades has established diet as an important modifiable risk factor for 
dementia in older populations. Various healthy dietary patterns [e.g., Mediterranean (Aridi et al., 2017), DASH (Tangney et al., 2014), MIND (Morris et al., 2015c)], foods (Morris et al., 2006, 2016, 2018; Devore et al., 2012; van de Rest et al., 2016; Samieri et al., 2018) and nutrients (Morris et al., 2002a,b, 2003, 2004, 2005, 2018; Haan et al., 2007; Moorthy et al., 2012; Beydoun et al., 2018b; Schneider et al., 2018) have been associated with slower cognitive decline and lower dementia risk in prospective cohort studies. The healthy dietary pattern may exert a neuroprotective effect by reducing oxidative stress and inflammation (Bagetta et al., 2020) and was found to be associated with less brain atrophy (Gu et al., 2015). These dietary patterns are plant-based consisting of foods such as fruits, berries, vegetables, leafy greens, whole grains, fish, olive oil, legumes, and nuts. These foods are rich in essential nutrients as well as bioactive that have anti-inflammatory and antioxidant properties (Ellis et al., 2011; Alvarez-Suarez et al., 2014; Giampieri et al., 2014). In vitro and in vivo evidence indicate that bioactive and some of their metabolites can cross the bloodbrain barrier (Youdim et al., 2003, 2004) and through signal transduction cascades may directly act on neurons and glia (Jaeger et al., 2018). Animal studies reported berries and leafy greens improve cognitive function via increased neurogenesis, and insulin-like growth factor-1 signaling, and reversed neuronal aging by reducing oxidative stress (Joseph et al., 1998; ShukittHale et al., 2015; Elkhadragy et al., 2018). Additionally, these dietary patterns also limit the consumption of red meat, fatty foods, and sweets. Another set of evidence indicate the high fat/cholesterol diet's deleterious effect on cognition via its effect on synaptic integrity, increased hippocampal insulin resistance, inflammation (Arnold et al., 2014; Denver et al., 2018), as well as increased levels of amyloid precursor protein (Thirumangalakudi et al., 2008).

The association of diet with cognitive decline and Alzheimer's dementia risk has emerged as important factor that may have huge public health impact on aging population. However, there is a paucity of information on how these associations may differ by race or ethnicity. Two primary reasons emerge to explain this gap. First, not all cohort studies include diet assessment, and those that do are almost exclusively of non-Hispanic white populations. Second, the few multi-racial/ethnic cohort studies that include diet rarely report the findings stratified by racial/ethnic groups (Koyama et al., 2015; Beydoun et al., 2018b), although some report $\mathrm{p}$-values for tests of interaction of the findings by these groups as discussed below.

Table 1 summarizes the findings from nine multi-racial/ethnic cohort studies in the US that report diet associations with dementia outcomes. The studies are large, ranging from 1,956 to 18,080 participants, and the percentages of minority participants provide sufficient sample sizes to observe most diet associations with the outcomes (percentages of minority groups range from 22 to 100\%). The non-white groups represented in these studies are African American and Puerto Rican. There is limited (Ye et al., 2013a,b) or non-existent data for Mexican, Native American, and Asian populations. The findings of studies on African Americans and Puerto Ricans cannot be assumed to apply to these other racial/ethnic groups as there are large cultural and social differences, including dietary practices.

As shown in Table 1, the multi-racial/ethnic cohort studies have a number of positive findings for dementia outcomes and nutrients (vitamin E, vitamin D, folate, vitamin B12, dietary fats), foods (vegetables, fish, caffeine, alcohol), and diet patterns. Some of the studies provide no information about whether the findings were analyzed by race/ethnicity (McEvoy et al., 2019), but in those that do, the findings are not stratified by racial/ethnic group. This is most likely because in nearly every case, tests for interaction effects by race/ethnicity are not statistically significant, although there are a few exceptions. The Health, Aging and Body Composition Study (Health ABC) reported a protective association of the Mediterranean diet with slower cognitive decline in African American but not in whites (Koyama et al., 2015), and a cross-sectional study from the HANDLS (Beydoun et al., 2018 b) found a positive association of dietary vitamin D and better visual memory in whites but not in African American. Even though most of these studies did not find statistically significant differences by race or ethnicity, the possibility of heterogeneous effects of diet on brain health by race remains. As discussed below, one must question whether dietary behaviors among the minority participants have been well characterized in these studies.

\section{METHODOLOGICAL ISSUES}

It is not enough to implement a standardized diet questionnaire into a multi-racial/ethnic cohort study and expect to elicit valid findings on diet and dementia by racial/ethnic groups. The diet assessment tool must represent the foods, cooking methods, recipes and portion sizes that are relevant to the population under study. For diet assessment tools, one size does not fit all. Food frequency questionnaires (FFQ) are the primary method of diet assessment in large epidemiological studies of chronic conditions. They provide a measure of long-term intake that is most relevant to conditions with long latency. This is in contrast to other methods, such as biochemical measures or 24-h dietary recall and diet recording, that may not be good representations of more habitual diet, particularly those nutrients that have high day-to-day variability (Willett, 2013). Although FFQs have been used as a valid and reproducible tool of dietary intake for many years, they are not generalizable beyond the populations for which they have been developed. This is particularly true for racial/ethnic groups as most FFQs were developed for nonHispanic white populations. FFQs have a predefined list of food items, to which participants respond regarding usual frequency of intake, and for some FFQs, usual portion size (e.g., small, medium, large). The list of foods and their corresponding frequencies and portion sizes vary among FFQs. Two FFQs that have been widely adopted for use by many of the cohort studies are those developed by Willett et al. (1985) (used in the Nurses' Health Study and Health Professional Follow-up Study) and Block et al. (1986) (used in the National Health and Nutrition Examination Survey, or NHANES). Both the 
TABLE 1 | Summary of studies on association of Dietary Patterns with cognitive decline or Incident AD that have at least > 20\% minority population included.

\begin{tabular}{|c|c|c|c|c|c|c|c|}
\hline Cohort and study population & $\begin{array}{l}\text { Minority } \\
\text { population\% }\end{array}$ & $\begin{array}{l}\text { Years } \\
\text { Follow-up }\end{array}$ & $\begin{array}{l}\mathrm{N} ; \text { Mean } \\
\text { Age (SD) }\end{array}$ & Exposure & Outcome & Findings & Exposure Interaction with Race \\
\hline \multirow{4}{*}{$\begin{array}{l}\text { WHICAP- Washington } \\
\text { Heights-Inwood Columbia Aging } \\
\text { Project } \\
\text { (Multi-racial) } 68 \% \text { Female }\end{array}$} & $\begin{array}{l}\text { African American } \\
(34 \%) \text { and } \\
\text { Hispanics (34\%) }\end{array}$ & $\begin{array}{l}\text { Longitudinal, } \\
4-5 \text { years }\end{array}$ & $\begin{array}{l}N=2258 \\
77.6(6.6)\end{array}$ & Mediterranean diet & $\begin{array}{l}\text { Incident } \mathrm{MCl} \\
\text { Progression of } \mathrm{MCl} \\
\text { to } \mathrm{AD}\end{array}$ & $\begin{array}{l}\downarrow \mathrm{MCl} \text { risk and } \downarrow \text { risk for } \mathrm{MCl} \\
\text { conversion to } \mathrm{AD} \text { (Scarmeas et al., } \\
\text { 2009) }\end{array}$ & Not reported \\
\hline & & & & $\begin{array}{l}\text { Healthy dietary pattern for } \\
\text { study population * }\end{array}$ & Incident AD & $\downarrow$ AD risk (Gu et al., 2010) & No stratified analysis by race \\
\hline & & & & Total calories and Fat intake & Incident AD & $\uparrow A D$ risk (Luchsinger et al., 2002) & \\
\hline & & & & Antioxidant vitamin & Incident AD & $\begin{array}{l}\text { No association (Luchsinger et al., } \\
\text { 2003) }\end{array}$ & \\
\hline \multirow[t]{9}{*}{$\begin{array}{l}\text { CHAP-Chicago Health and Aging } \\
\text { Project }\end{array}$} & $\begin{array}{l}\text { African American } \\
(63 \%)\end{array}$ & $\begin{array}{l}\text { Longitudinal, } \\
6-9 \text { years }\end{array}$ & $\begin{array}{l}N=3790 \\
75.4(6.2)\end{array}$ & $\begin{array}{l}\text { Mediterranean diet, } \\
\text { HEI-2005 }\end{array}$ & $\begin{array}{l}\text { Cognitive decline } \\
\text { OR } \\
\text { Incident AD }\end{array}$ & $\begin{array}{l}\text { Mediterranean diet } \downarrow \text { cognitive } \\
\text { decline (Tangney et al., 2011) }\end{array}$ & $\begin{array}{l}\text { Diet*race not significant } \\
\text { No stratified analysis by race }\end{array}$ \\
\hline & & & & Fruits and Vegetables & & $\begin{array}{l}\text { Vegetable intake } \downarrow \text { cognitive decline } \\
\text { (Morris et al., 2006) }\end{array}$ & Dietrace not significant \\
\hline & & & & Fish intake & & $\begin{array}{l}\text { n-3 FA } \downarrow \text { AD risk (Morris et al., } \\
\text { 2003) }\end{array}$ & Diet$^{\star}$ race not significant \\
\hline & & & & Antioxidant vitamins & & $\begin{array}{l}\text { Vitamin E from foods } \downarrow \text { cognitive } \\
\text { decline (Morris et al., 2002b) } \\
\downarrow \text { AD risk (Morris et al., 2002a) }\end{array}$ & Diet$^{\star}$ race not significant \\
\hline & & & & $\begin{array}{l}\text { Folate } \\
\text { Vitamin B12 }\end{array}$ & & $\begin{array}{l}\uparrow \text { Cognitive decline (Morris et al., } \\
2005 \text { ) } \\
\downarrow \text { Cognitive decline (Morris et al., } \\
2005 \text { ) }\end{array}$ & Diet$^{\star}$ race not significant \\
\hline & & & & Dietary fats & & $\begin{array}{l}\text { Saturated fats } \uparrow \text { cognitive decline } \\
\text { (Morris et al., 2004) }\end{array}$ & Animal fat ${ }^{\star}$ race was not significant. \\
\hline & & & & $\begin{array}{l}\text { Serum } \\
\text { Vitamin B12 }\end{array}$ & & $\begin{array}{l}\downarrow \text { Cognitive decline (Tangney et al., } \\
\text { 2009) }\end{array}$ & $\begin{array}{l}\text { Vitamin } B 12^{*} \text { race was not } \\
\text { significant }\end{array}$ \\
\hline & & & & Homocysteine & & No association & $\begin{array}{l}\text { Homocysteine* race was not } \\
\text { significant }\end{array}$ \\
\hline & & & & Methyl malonic acid & & $\begin{array}{l}\uparrow \text { Cognitive decline (Tangney et al., } \\
\text { 2009) }\end{array}$ & $\begin{array}{l}\text { Methyl malonic acid race was not } \\
\text { significant. }\end{array}$ \\
\hline $\begin{array}{l}\text { Health ABC - Health Aging and } \\
\text { Body Composition Study } \\
\text { (Biracial) }\end{array}$ & $\begin{array}{l}\text { African American } \\
(38 \%)\end{array}$ & $\begin{array}{l}\text { Longitudinal, } \\
8.0 \text { years }\end{array}$ & $\begin{array}{l}N=2326 \\
74.6(2.9)\end{array}$ & Mediterranean diet & Cognitive decline & $\begin{array}{l}\downarrow \text { Cognitive decline in Blacks not } \\
\text { Whites (Koyama et al., 2015) }\end{array}$ & $\begin{array}{l}\text { Mediterranean dietrace was } \\
\text { significant } \\
\text { Stratified analysis by race }\end{array}$ \\
\hline \multirow[t]{2}{*}{$\begin{array}{l}\text { Health and Retirement study } \\
60 \% \text { women }\end{array}$} & $\begin{array}{l}\text { African American } \\
(22 \%)\end{array}$ & Cross-sectional & $\begin{array}{l}N=5907 \\
68(10.8)\end{array}$ & Mediterranean diet & Cognitive Scores & $\begin{array}{l}\text { "+ " Cognition (McEvoy et al., } \\
\text { 2017) }\end{array}$ & Not reported \\
\hline & & & & MIND diet & & " + " Cognition & \\
\hline $\begin{array}{l}\text { Coronary Artery Risk Development } \\
\text { in Young Adults (CARDIA) }\end{array}$ & $\begin{array}{l}\text { African American } \\
(45 \%)\end{array}$ & $\begin{array}{l}\text { Longitudinal, } \\
8.0 \text { years }\end{array}$ & $\begin{array}{l}N=2621 \\
25(3.5)\end{array}$ & Mediterranean diet & $\begin{array}{l}\text { Cognitive Scores } \\
\text { assessed } 25 \text { and } \\
30 \text { years later }\end{array}$ & $\begin{array}{l}\uparrow \text { Cognitive function in midlife } \\
\text { (McEvoy et al., 2019) }\end{array}$ & Not reported \\
\hline $57 \%$ female & & & & DASH diet & & No association & \\
\hline
\end{tabular}


TABLE 1 | Continued

\begin{tabular}{|c|c|c|c|c|c|c|c|}
\hline Cohort and study population & $\begin{array}{l}\text { Minority } \\
\text { population\% }\end{array}$ & $\begin{array}{l}\text { Years } \\
\text { Follow-up }\end{array}$ & $\begin{array}{l}\text { N; Mean } \\
\text { Age (SD) }\end{array}$ & Exposure & Outcome & Findings & $\begin{array}{l}\text { Exposure Interaction with } \\
\text { Race }\end{array}$ \\
\hline & & & & $\begin{array}{l}\text { A Priori Dietary } \\
\text { Quality Index }\end{array}$ & & $\begin{array}{l}\uparrow \text { Cognitive function in midlife } \\
\text { (McEvoy et al., 2019) }\end{array}$ & \\
\hline \multirow[t]{2}{*}{$\begin{array}{l}\text { REGARDS- REasons for } \\
\text { Geographic And Racial Differences } \\
\text { in Stroke }\end{array}$} & $\begin{array}{l}\text { African American } \\
(31 \%)\end{array}$ & $\begin{array}{l}\text { Longitudinal } \\
4-7 \text { years }\end{array}$ & $\begin{array}{l}N=18,080 \\
64.4(9.1)\end{array}$ & $\begin{array}{l}\text { Plant-based diet } \\
\text { Southern diet }\end{array}$ & $\begin{array}{l}\text { Incident cognitive } \\
\text { Impairment }\end{array}$ & $\begin{array}{l}\downarrow \text { Incident cognitive impairment } \\
\text { (Pearson et al., 2016) } \\
\uparrow \text { Incident cognitive impairment } \\
\text { (Pearson et al., 2016) }\end{array}$ & $\begin{array}{l}\text { Diet*race not significant } \\
\text { No stratified analysis by race }\end{array}$ \\
\hline & & & & Mediterranean diet & & $\begin{array}{l}\downarrow \text { Incident cognitive Impairment } \\
\text { in non-diabetic participants } \\
\text { (Tsivgoulis et al., 2013) }\end{array}$ & $\begin{array}{l}\text { Only Diet*diabetes significant. } \\
\text { Stratified by diabetes status }\end{array}$ \\
\hline \multirow{4}{*}{$\begin{array}{l}\text { HANDLS (Healthy Aging in the } \\
\text { Neighborhood of Diversity Across } \\
\text { Lifespan) } \\
\text { Participants } \\
\text { (Biracial) } 57 \% \text { female }\end{array}$} & $\begin{array}{l}\text { African American } \\
(51 \%)\end{array}$ & Cross-sectional & $\begin{array}{l}N=2090 \\
47.9(9.2)\end{array}$ & HEI-2010 & Cognitive Scores & $\begin{array}{l}\text { "+ " Cognition only in those } \\
\text { below the poverty line } \\
\text { (Beydoun et al., 2018a) }\end{array}$ & $\begin{array}{l}\text { Diet*race not significant } \\
\text { No stratified analysis by race }\end{array}$ \\
\hline & & & & $\begin{array}{l}\text { Dietary Antioxidant } \\
\text { vitamins }\end{array}$ & & $\begin{array}{l}\text { Vitamin E " + " Cognition } \\
\text { (Beydoun et al., 2015) }\end{array}$ & $\begin{array}{l}\text { Vitamin } \mathrm{E}^{\star} \text { race not significant } \\
\text { No stratified analysis by race }\end{array}$ \\
\hline & & $\begin{array}{l}\text { Longitudinal, } \\
4-5 \text { years }\end{array}$ & & Dietary Vitamin D & Cognitive decline & $\begin{array}{l}\downarrow \text { Cognitive decline (visual } \\
\text { memory) (Beydoun et al., } \\
\text { 2018b) }\end{array}$ & $\begin{array}{l}\text { Vitamin } D^{*} \text { race interaction } \\
\text { significant: Improved visual } \\
\text { memory only in Whites and not } \\
\text { in Blacks }\end{array}$ \\
\hline & & & & $\begin{array}{l}\text { Nutrient adequacy } \\
\text { score (NAS) } \\
\text { Caffeine } \\
\text { Alcohol }\end{array}$ & & $\begin{array}{l}\text { "+ " Cognition } \\
\downarrow \text { Attention decline (Beydoun } \\
\text { et al., 2014) } \\
\text { " + " Cognition } \\
\text { "+ " Attention and Working } \\
\text { memory (Beydoun et al., 2014) }\end{array}$ & $\begin{array}{l}\text { NAS*race not significant } \\
\text { No stratified analysis by race }\end{array}$ \\
\hline $\begin{array}{l}\text { Two Boston based cohorts (Boston } \\
\text { Puerto Rican Health Study } \\
\text { (BPRHS) and Nutrition, Aging and } \\
\text { Memory in Elders (NAME) study) }\end{array}$ & $\begin{array}{l}\text { African American } \\
(37 \%) \\
\text { BPRHS- Hispanics } \\
(100 \%)\end{array}$ & Cross-sectional & $N=1956$ & $\begin{array}{l}\text { Plasma } \\
\text { Vitamin B12 } \\
\text { Vitamin B6 } \\
\text { Folate } \\
\text { Homocysteine }\end{array}$ & Cognitive Scores & $\begin{array}{l}\text { "+ " Cognition (Moorthy et al., } \\
2012 \text { ) } \\
\text { "+ " Cognition } \\
\text { No association } \\
\text { No association }\end{array}$ & $\begin{array}{l}\text { Not reported } \\
\text { No stratified analysis by race }\end{array}$ \\
\hline \multirow[t]{5}{*}{$\begin{array}{l}\text { BPRHS (Boston Puerto Rican } \\
\text { Health Study), } 70 \% \text { female }\end{array}$} & Hispanics (100\%) & Cross-sectional & $\begin{array}{l}N=1269 \\
57.3(7.6)\end{array}$ & $\begin{array}{l}\text { Mediterranean diet } \\
\text { HEl-2005 }\end{array}$ & $\begin{array}{l}\text { Cognitive } \\
\text { Impairment }\end{array}$ & $\begin{array}{l}\text { "-"cognitive impairment (Ye } \\
\text { et al., 2013b) }\end{array}$ & $N / A$ \\
\hline & & & & $\begin{array}{l}\text { Fruits and } \\
\text { Vegetables }\end{array}$ & & $\begin{array}{l}\text { "-" Cognitive Impairment (Ye } \\
\text { et al., 2013a) }\end{array}$ & \\
\hline & & $\begin{array}{l}\text { Longitudinal } \\
2 \text { years }\end{array}$ & & $\begin{array}{l}\text { Dietary n-3 and n-6 } \\
\text { PUFA }\end{array}$ & Cognitive decline & $\begin{array}{l}\text { EPA, DHA and n3VLCFA } \\
\uparrow \text { Executive Function (Bigornia } \\
\text { et al., 2018) }\end{array}$ & \\
\hline & & & & Plasma vitamin B-6 & & $\begin{array}{l}\downarrow \text { Cognitive decline (Palacios } \\
\text { et al., 2019a) }\end{array}$ & \\
\hline & & & & Serum vitamin $D$ & & $\begin{array}{l}\text { No association (Palacios et al., } \\
\text { 2019b) }\end{array}$ & \\
\hline
\end{tabular}

$\uparrow$ Upward arrow indicates statistically significant increased risk in longitudinal analysis; $\downarrow$ downward arrow indicates statistically significant decreased risk in longitudinal analysis; " + " Plus indicates statistically significant positive association in the cross-sectional analysis; "-" Minus indicates statistically significant negative association in the cross-sectional analysis. *Dietary pattern for study population identified based on Reduced Rank Regression. 
Willett and Block FFQs have been well-validated by biochemical measures and other assessment methods of dietary intake, but their development and validation have been primarily in majority white populations. Thus, implementation of these tools in study populations that include other racial and ethnic groups without validating them raises concerns as to the validity of the study findings. It is possible that the absence of racial/ethnic differences in the diet-dementia findings in Table $\mathbf{1}$ is due in part to the lower validity of the diet assessment tools to capture intake in the minority groups in some cohorts. Only a few of the cohort studies conducted validation studies of the FFQ within their study populations. Of these few, the validation correlations were somewhat moderate for Chicago Health and Aging Project participants (average $r=0.41$ in African American vs. $r=0.51$ in whites for 15 nutrients), and the WHICAP studies ( $r=0.40$ for 7 nutrients, correlations not reported by race/ethnicity). To validly assess diet, the FFQ should capture the most commonly consumed food items for a group as well as culture-specific recipes, cooking methods, and portion sizes. For example, Hispanics consume a bigger rice portion in one meal compared to whites and African American (Tucker et al., 1998). The standard portion size for rice among Puerto Ricans may be 1 cup versus $1 / 2$ cup in non-Hispanic whites (Tucker et al., 1998). Food preparations, preference, cooking methods and recipes of dishes may vary too. For example, one study documented that soul food, a common dietary pattern found in African American culture, contains mainly pork, pork fat, chicken, organ meats, corn, sweet potatoes, and greens (Sucher and Kittler, 2004). The diets of different race/ethnicities in a study population will be well measured only to the extent that the appropriate foods, portions and preparation methods are accurately captured by the assessment method; for example, the Boston Puerto Rican Health Study uses a validated FFQ specifically designed and processed as per the Puerto Rican dietary habits. Similarly, the Jackson Heart Study used a validated FFQ developed based on regional food patterns rather than on the national patterns for whites and African Americans in the lower Mississippi Delta region (Tucker et al., 2007). Thus capturing diet using a validated tool for multiethnic populations is an important gap that can be improved in the field of diet and dementia.

The majority of studies on nutrition and dementia outcomes primarily based their findings on dietary intake levels of nutrients and foods. However, our knowledge about nutritional effects on the brain would be greatly enhanced by the addition of biochemical measures. There may be differences in nutrient absorption, metabolism, or delivery to tissues that require different intake levels by race/ethnicity for optimum brain function and disease prevention. The use of biochemical measures in conjunction with dietary intake assessments could be used to better inform public policy on recommended dietary intake levels by race. The reporting of dementia outcomes by level of nutrient intake as well as biochemical level is crucial to advance the field as well as to establish public health and clinical recommendations. Published studies rarely present this information stratified by race or ethnic group; even fewer report biochemical assessments.

Currently, there is much attention on the Mediterranean diet for dementia prevention. However, the promotion of one diet pattern for diverse cultures around the world may not be optimal from the perspective of public health or the environment. It is becoming evident that there are multiple diet patterns favorable to brain health. Given the challenges in achieving behavior change over the long-term, it does not appear feasible to expect individuals to adopt a single diet from a foreign culture that involves introducing new foods that are strange to one's usual cultural practices, or the elimination of favorite meal items. This approach to behavior change has a high likelihood of failure, particularly if the changes are more expensive. A "one diet" approach to health also would not prove favorable for environmental health. The ecological or carbon footprint may be unnecessarily large due to shipping and storage, particularly if there are local foods and diets that are equally beneficial for maintaining brain health. By studying nutrition and brain health in different cultures, regions, and races, we can identify multiple brain-healthy diets within a region and group. This is another large gap in the field.

\section{FUTURE RESEARCH}

In order to advance the field on nutrition and dementia in minority populations, it is imperative that the few studies with large minority populations report estimates of effect stratified by racial/ethnic group, at the very least in supplemental tables. In addition, new multi-racial/ethnic cohort studies are needed that include culturally appropriate and validated diet assessments as well as biochemical measures of nutrient status. Currently, there is limited data on a number of large minority populations in the U.S., particularly those originating from Mexico and other Latin American countries, Asia, and Native Americans. The inclusion of diverse cultures in a study lends to a greater range of nutrient intake levels and thus improved ability to observe diet-dementia relations. The diversity in dietary practices may also lead to discoveries of new nutrients and foods that are important in the disease process. Additionally, we need to understand how cognition is related to the nutrigenomics and nutrigenetics, i.e., two-level interaction between nutrients and genomics. Firstly, nutrients may affect transcriptional factors and modify the gene expression. Secondly, the genetic variability may define the interaction between nutrients and the disease (Fenech et al., 2011; Peña-Romero et al., 2018). Precision nutrition is gaining popularity for other disease outcomes, and future studies in the field of nutrition and cognition focusing on the genetic factors that may alter the relation of various foods with the brain health are needed. The emerging science on the gut microbiome and the gutbrain axis is a new frontier in the dementia field that would be greatly enhanced by diversity in diet that comes with the inclusion of multiple cultures within a study. Another frontier is the measurement of nutrients and metabolites in human brain tissue (Morris et al., 2003, 2015a) and their relations to measures of brain neuropathology. To date, these rare studies have largely been restricted to non-Hispanic whites. Finally, the first diet intervention trials on cognitive health have been initiated. Efforts to test diet approaches in multiple racial/ethnic groups is imperative for better understanding of the disease 
process and for more effective public health policies to reduce racial/ethnic disparities in dementia.

\section{AUTHOR CONTRIBUTIONS}

PA: manuscript preparation and critical review. MM and LB: manuscript preparation and critical review of the manuscript for

\section{REFERENCES}

Agarwal, P., Holland, T. M., Wang, Y., Bennett, D. A., and Morris, M. C. (2019). Association of Strawberries and anthocyanidin intake with Alzheimer's dementia risk. Nutrients 11:3060. doi: 10.3390/nu11123060

Aggarwal, A., Monsivais, P., and Drewnowski, A. (2012). Nutrient intakes linked to better health outcomes are associated with higher diet costs in the us. PloS One 7:e37533. doi: 10.1371/journal.pone.0037533

Alvarez-Suarez, J. M., Giampieri, F., Tulipani, S., Casoli, T., Di Stefano, G., Gonzalez-Paramas, A. M., et al. (2014). One-month strawberry-rich anthocyanin supplementation ameliorates cardiovascular risk, oxidative stress markers and platelet activation in humans. J. Nutr. Biochem. 25, 289-294. doi: 10.1016/j.jnutbio.2013.11.002

Alzheimer's Association (2018). 2018 Alzheimer's disease facts and figures. Alzheimers Dement. 14, 367-429. doi: 10.1016/j.jalz.2018.02.001

Aridi, Y. S., Walker, J. L., and Wright, O. R. L. (2017). The association between the mediterranean dietary pattern and cognitive health: a systematic review. Nutrients 9:674. doi: 10.3390/nu9070674

Arnold, S. E., Lucki, I., Brookshire, B. R., Carlson, G. C., Browne, C. A., Kazi, H., et al. (2014). High fat diet produces brain insulin resistance, synaptodendritic abnormalities and altered behavior in mice. Neurobiol. Dis. 67, 79-87. doi: 10.1016/j.nbd.2014.03.011

Bagetta, D., Maruca, A., Lupia, A., Mesiti, F., Catalano, R., Romeo, I., et al. (2020). Mediterranean products as promising source of multi-target agents in the treatment of metabolic syndrome. Eur. J. Med. Chem. 186:111903. doi: 10.1016/j.ejmech.2019.111903

Berendsen, A. M., Kang, J. H., Feskens, E. J. M., de Groot, C., Grodstein, F., and van de Rest, O. (2018). Association of long-term adherence to the mind diet with cognitive function and cognitive decline in american women. J. Nutr. Health Aging 22, 222-229. doi: 10.1007/s12603-017-0909-0

Beydoun, M. A., Fanelli-Kuczmarski, M. T., Kitner-Triolo, M. H., Beydoun, H. A., Kaufman, J. S., Mason, M. A., et al. (2015). Dietary antioxidant intake and its association with cognitive function in an ethnically diverse sample of us adults. Psychosom. Med. 77, 68-82. doi: 10.1097/psy.0000000000000129

Beydoun, M. A., Fanelli-Kuczmarski, M. T., Poti, J., Allen, A., Beydoun, H. A., Evans, M. K., et al. (2018a). Longitudinal change in the diet's monetary value is associated with its change in quality and micronutrient adequacy among urban adults. PloS One 13:e0204141. doi: 10.1371/journal.pone.0204141

Beydoun, M. A., Gamaldo, A. A., Beydoun, H. A., Tanaka, T., Tucker, K. L., Talegawkar, S. A., et al. (2014). Caffeine and alcohol intakes and overall nutrient adequacy are associated with longitudinal cognitive performance among u.s. adults. J. Nutr. 144, 890-901. doi: 10.3945/jn.113.189027

Beydoun, M. A., Hossain, S., Fanelli-Kuczmarski, M. T., Beydoun, H. A., Canas, J. A., Evans, M. K., et al. (2018b). Vitamin d status and intakes and their association with cognitive trajectory in a longitudinal study of urban adults. J. Clin. Endocrinol. Metab. 103, 1654-1668. doi: 10.1210/jc.2017-02462

Bhupathiraju, S. N., Dawson-Hughes, B., Hannan, M. T., Lichtenstein, A. H., and Tucker, K. L. (2011). Centrally located body fat is associated with lower bone mineral density in older puerto rican adults. Am. J. Clin. Nutr. 94, 1063-1070. doi: 10.3945/ajcn.111.016030

Bhushan, A., Fondell, E., Ascherio, A., Yuan, C., Grodstein, F., and Willett, W. (2018). Adherence to mediterranean diet and subjective cognitive function in men. Eur. J. Epidemiol. 33, 223-234. doi: 10.1007/s10654-017-0330-3

Bigornia, S. J., Scott, T. M., Harris, W. S., and Tucker, K. L. (2018). Prospective associations of erythrocyte composition and dietary intake of n-3 and n-6 pufa with measures of cognitive function. Nutrients 10 , intellectual content. All authors contributed to the article and approved the submitted version.

\section{FUNDING}

The work was supported by the National Institute on Aging of Health (R01AG052583 to LB).

Block, G., Hartman, A. M., Dresser, C. M., Carroll, M. D., Gannon, J., Gardner L., et al. (1986). Approach to diet questionnaire design and testing. Am. J. Epidemiol. 124, 453-469. doi: 10.1093/oxfordjournals.aje.a114416

Bloom, I., Edwards, M., Jameson, K. A., Syddall, H. E., Dennison, E., Gale, C. R., et al. (2017). Influences on diet quality in older age: the importance of social factors. Age Ageing 46, 277-283.

Bower, K. M., Thorpe, R. J. Jr., Rohde, C., and Gaskin, D. J. (2014). The intersection of neighborhood racial segregation, poverty, and urbanicity and its impact on food store availability in the united states. Prev. Med. 58, 33-39. doi: 10.1016/j. ypmed.2013.10.010

Brown, S. C., Perrino, T., Lombard, J., Wang, K., Toro, M., Rundek, T., et al. (2018). Health disparities in the relationship of neighborhood greenness to mental health outcomes in 249,405 U.S. medicare beneficiaries. Int. J. Environ. Res. Public Health 15:430. doi: 10.3390/ijerph15030430

Brownley, K. A., Light, K. C., Grewen, K. M., Bragdon, E. E., Hinderliter, A. L., and West, S. G. (2004). Postprandial ghrelin is elevated in black compared with white women. J. Clin. Endocrinol. Metab. 89, 4457-4463. doi: 10.1210/jc.20040607

Colby, S. L., and Ortman, J. M. (2014). Projections of the Size and Composition of the U.S. Population: 2014 to 2060, Current Population Reports P25-1143. Washington, DC: U.S. Census Bureau.

Denver, P., Gault, V. A., and McClean, P. L. (2018). Sustained high-fat diet modulates inflammation, insulin signalling and cognition in mice and a modified xenin peptide ameliorates neuropathology in a chronic high-fat model. Diabetes Obes. Metab. 20, 1166-1175. doi: 10.1111/dom.13210

Devore, E. E., Kang, J. H., Breteler, M. M., and Grodstein, F. (2012). Dietary intakes of berries and flavonoids in relation to cognitive decline. Ann. Neurol. 72, 135-143. doi: 10.1002/ana.23594

Diaz-Venegas, C., Downer, B., Langa, K. M., and Wong, R. (2016). Racial and ethnic differences in cognitive function among older adults in the USA. Int. J. Geriatr. Psychiatry 31, 1004-1012. doi: 10.1002/gps.4410

Elkhadragy, M. F., Kassab, R. B., Metwally, D., Almeer, R. S., Abdel-Gaber, R., AlOlayan, E. M., et al. (2018). Protective effects of fragaria ananassa methanolic extract in a rat model of cadmium chloride-induced neurotoxicity. Biosci. Rep 38:BSR20180861.

Ellis, C. L., Edirisinghe, I., Kappagoda, T., and Burton-Freeman, B. (2011). Attenuation of meal-induced inflammatory and thrombotic responses in overweight men and women after 6-week daily strawberry (fragaria) intake. a randomized placebo-controlled trial. J. atheroscler. Thromb. 18, 318-327. doi: $10.5551 /$ jat.6114

Fenech, M., El-Sohemy, A., Cahill, L., Ferguson, L. R., French, T. A., Tai, E. S., et al. (2011). Nutrigenetics and nutrigenomics: viewpoints on the current status and applications in nutrition research and practice. J. Nutrigenet. Nutrigenomics 4, 69-89. doi: 10.1159/000327772

Gallagher, J. C., Peacock, M., Yalamanchili, V., and Smith, L. M. (2013). Effects of vitamin d supplementation in older african american women. J. Clin. Endocrinol. Metab. 98, 1137-1146. doi: 10.1210/jc.2012-3106

Giampieri, F., Alvarez-Suarez, J. M., Mazzoni, L., Forbes-Hernandez, T. Y., Gasparrini, M., Gonzalez-Paramas, A. M., et al. (2014). Polyphenol-rich strawberry extract protects human dermal fibroblasts against hydrogen peroxide oxidative damage and improves mitochondrial functionality. Molecules 19, 7798-7816. doi: 10.3390/molecules19067798

Goff, L. M., Whyte, M. B., Samuel, M., and Harding, S. V. (2016). Significantly greater triglyceridemia in black african compared to white european men following high added fructose and glucose feeding: a randomized crossover trial. Lipids Health Dis. 15:145. 
Gu, Y., Brickman, A. M., Stern, Y., Habeck, C. G., Razlighi, Q. R., Luchsinger, J. A., et al. (2015). Mediterranean diet and brain structure in a multiethnic elderly cohort. Neurology 85, 1744-1751. doi: 10.1212/wnl.0000000000002121

Gu, Y., Nieves, J. W., Stern, Y., Luchsinger, J. A., and Scarmeas, N. (2010). Food combination and alzheimer disease risk: a protective diet. Arch. Neurol. 67, 699-706. doi: 10.1001/archneurol.2010.84

Haan, M. N., Miller, J. W., Aiello, A. E., Whitmer, R. A., Jagust, W. J., Mungas, D. M., et al. (2007). Homocysteine, b vitamins, and the incidence of dementia and cognitive impairment: results from the sacramento area latino study on aging. Am. J. Clin. Nutr. 85, 511-517. doi: 10.1093/ajcn/85.2.511

Haffner, S. M., D’Agostino, R., Saad, M. F., Rewers, M., Mykkanen, L., Selby, J., et al. (1996). Increased insulin resistance and insulin secretion in nondiabetic african-americans and hispanics compared with non-hispanic whites. The insulin resistance atherosclerosis study. Diabetes 45, 742-748. doi: 10.2337/ diabetes.45.6.742

Hall, L. M., Kimlin, M. G., Aronov, P. A., Hammock, B. D., Slusser, J. R., Woodhouse, L. R., et al. (2010). Vitamin d intake needed to maintain target serum 25-hydroxyvitamin d concentrations in participants with low sun exposure and dark skin pigmentation is substantially higher than current recommendations. J. Nutr. 140, 542-550. doi: 10.3945/jn.109.115253

Hebert, L. E., Weuve, J., Scherr, P. A., and Evans, D. A. (2013). Alzheimer disease in the united states (2010-2050) estimated using the 2010 census. Neurology 80 , 1778-1783. doi: 10.1212/wnl.0b013e31828726f5

Hiza, H. A., Casavale, K. O., Guenther, P. M., and Davis, C. A. (2013). Diet quality of americans differs by age, sex, race/ethnicity, income, and education level. J. Acad. Nutr. Diet. 113, 297-306. doi: 10.1016/j.jand.2012.08.011

Holland, T. M., Agarwal, P., Wang, Y., Leurgans, S. E., Bennett, D. A., Booth, S. L., et al. (2020). Dietary flavonols and risk of alzheimer dementia. Neurology 94, e1749-e1756.

Howard, G., Cushman, M., Moy, C. S., Oparil, S., Muntner, P., Lackland, D. T., et al. (2018). Association of clinical and social factors with excess hypertension risk in black compared with white us adults. JAMA 320, 1338-1348. doi: 10.1001/jama.2018.13467

Huang, H. Y., Helzlsouer, K. J., and Appel, L. J. (2000). The effects of vitamin c and vitamin e on oxidative dna damage: results from a randomized controlled trial. Cancer Epidemiol. Biomarkers Prev. 9, 647-652.

Jaeger, B. N., Parylak, S. L., and Gage, F. H. (2018). Mechanisms of dietary flavonoid action in neuronal function and neuroinflammation. Mol. Aspects Med. 61, 50-62. doi: 10.1016/j.mam.2017.11.003

Joseph, J. A., Shukitt-Hale, B., Denisova, N. A., Prior, R. L., Cao, G., Martin, A., Taglialatela, G., et al. (1998). Long-term dietary strawberry, spinach, or vitamin e supplementation retards the onset of age-related neuronal signaltransduction and cognitive behavioral deficit. J. Neurosci. 1, 8047-8055. doi: 10.1523/jneurosci.18-19-08047.1998

Judd, S. E., Gutierrez, O. M., Newby, P. K., Howard, G., Howard, V. J., Locher, J. L., et al. (2013). Dietary patterns are associated with incident stroke and contribute to excess risk of stroke in black americans. Stroke 44, 3305-3311. doi: 10.1161/strokeaha.113.002636

Koyama, A., Houston, D. K., Simonsick, E. M., Lee, J. S., Ayonayon, H. N., Shahar, D. R., et al. (2015). Association between the mediterranean diet and cognitive decline in a biracial population. J. Gerontol. A. Biol. Sci. Med. Sci. 70, 354-359. doi: 10.1093/gerona/glu097

Kuczmarski, M. F., Adams, E. L., Cotugna, N., Pohlig, R. T., Beydoun, M. A., Zonderman, A. B., et al. (2016). Health literacy and education predict nutrient quality of diet of socioeconomically diverse, urban adults. J. Epidemiol. Prev. Med. 2:13000115.

Lamar, M., Leon, A., Romo, K., Durazo-Arvizu, R. A., Sachdeva, S., Lipton, R. B., et al. (2019). The independent and interactive associations of bilingualism and sex on cognitive performance in hispanics/latinos of the hispanic community health study/study of latinos. J. Alzheimers Dis. 71, 1271-1283. doi: 10.3233/ jad-190019

Lear, S. A., Kohli, S., Bondy, G. P., Tchernof, A., and Sniderman, A. D. (2009). Ethnic variation in fat and lean body mass and the association with insulin resistance. J. Clin. Endocrinol. Metab. 94, 4696-4702. doi: 10.1210/jc.2009-1030

Lee-Kwan, S. H., Moore, L. V., Blanck, H. M., Harris, D. M., and Galuska, D. (2017). Disparities in state-specific adult fruit and vegetable consumption united states, 2015. MMWR 66, 1241-1247. doi: 10.15585/mmwr.mm6645a1
Luchsinger, J. A., Tang, M. X., Shea, S., and Mayeux, R. (2002). Caloric intake and the risk of alzheimer disease. Arch. Neurol. 59, 1258-1263. doi: 10.1001/ archneur.59.8.1258

Luchsinger, J. A., Tang, M. X., Shea, S., and Mayeux, R. (2003). Antioxidant vitamin intake and risk of alzheimer disease. Arch. Neurol. 60, 203-208. doi: 10.1001/ archneur.60.2.203

McEvoy, C. T., Guyer, H., Langa, K. M., and Yaffe, K. (2017). Neuroprotective diets are associated with better cognitive function: the health and retirement study. J. Am. Geriatr. Soc. 65, 1857-1862. doi: 10.1111/jgs.14922

McEvoy, C. T., Hoang, T., and Sidney, S. (2019). Dietary patterns during adulthood and cognitive performance in midlife: the cardia study. Neurology 92, e1589e1599.

McInerney, M., Csizmadi, I., Friedenreich, C. M., Uribe, F. A., Nettel-Aguirre, A., McLaren, L., et al. (2016). Associations between the neighbourhood food environment, neighbourhood socioeconomic status, and diet quality: an observational study. BMC Public Health 16:984. doi: 10.1186/s12889-016-3 631-7

Mehta, K. M., and Yeo, G. W. (2017). Systematic review of dementia prevalence and incidence in united states race/ethnic populations. Alzheimers Dement. 13, 72-83. doi: 10.1016/j.jalz.2016.06.2360

Moorthy, D., Peter, I., Scott, T. M., Parnell, L. D., Lai, C. Q., Crott, J. W., et al. (2012). Status of vitamins b-12 and b-6 but not of folate, homocysteine, and the methylenetetrahydrofolate reductase $c 677 \mathrm{t}$ polymorphism are associated with impaired cognition and depression in adults. J. Nutr. 142, 1554-1560. doi: 10.3945/jn.112.161828

Morris, M. C., Brockman, J., Schneider, J. A., Wang, Y., Bennett, D. A., Tangney, C. C., et al. (2016). Association of seafood consumption, brain mercury level, and apoe epsilon 4 status with brain neuropathology in older adults. Jama 315, 489-497. doi: 10.1001/jama.2015.19451

Morris, M. C., Evans, D. A., Bienias, J. L., Tangney, C. C., Bennett, D. A., Aggarwal, N., et al. (2002a). Dietary intake of antioxidant nutrients and the risk of incident alzheimer disease in a biracial community study. JAMA 287, 3230-3237. doi: 10.1001/jama.287.24.3230

Morris, M. C., Evans, D. A., Bienias, J. L., Tangney, C. C., and Wilson, R. S. (2002b). Vitamin e and cognitive decline in older persons. Arch. Neurol. 59, 1125-1132. doi: 10.1001/archneur.59.7.1125

Morris, M. C., Evans, D. A., Bienias, J. L., Tangney, C. C., and Wilson, R. S. (2004). Dietary fat intake and 6-year cognitive change in an older biracial community population. Neurology 62, 1573-1579. doi: 10.1212/01.wnl.0000123250.828 $49 . \mathrm{b} 6$

Morris, M. C., Evans, D. A., Bienias, J. L., Tangney, C. C., Bennett, D. A., Wilson, R. S., et al. (2003). Consumption of fish and n-3 fatty acids and risk of incident alzheimer disease. Arch. Neurol. 60, 940-946. doi: 10.1001/archneur.60.7.940

Morris, M. C., Evans, D. A., Bienias, J. L., Tangney, C. C., Hebert, L. E., Scherr, P. A., et al. (2005). Dietary folate and vitamin b12 intake and cognitive decline among community-dwelling older persons. Arch. Neurol. 62, 641-645. doi: 10.1001/archneur.62.4.641

Morris, M. C., Evans, D. A., Tangney, C. C., Bienias, J. L., and Wilson, R. S. (2006). Associations of vegetable and fruit consumption with age-related cognitive change. Neurology 67, 1370-1376. doi: 10.1212/01.wnl.0000240224.38978.d8

Morris, M. C., Schneider, J. A., Li, H., Tangney, C. C., Nag, S., Bennett, D. A., et al. (2015a). Brain tocopherols related to Alzheimer's disease neuropathology in humans. Alzheimers Dement. 11, 32-39. doi: 10.1016/j.jalz.2013.12.015

Morris, M. C., Tangney, C. C., Wang, Y., Sacks, F. M., Bennett, D. A., Aggarwal, N. T., et al. (2015b). MIND diet associated with reduced incidence of Alzheimer's disease. Alzheimers Dement. 11, 1007-1014. doi: 10.1016/j.jalz. 2014.11.009

Morris, M. C., Tangney, C. C., Wang, Y., Sacks, F. M., Barnes, L. L., Bennett, D. A., et al. (2015c). MIND diet slows cognitive decline with aging. Alzheimers Dement. 11, 1015-1022. doi: 10.1016/j.jalz.2015.04.011

Morris, M. C., Wang, Y., Barnes, L. L., Bennett, D. A., Dawson-Hughes, B., and Booth, S. L. (2018). Nutrients and bioactives in green leafy vegetables and cognitive decline: prospective study. Neurology 90, e214-e222.

Morton, D. J., Barrett-Connor, E., Kritz-Silverstein, D., Wingard, D. L., and Schneider, D. L. (2003). Bone mineral density in postmenopausal caucasian, filipina, and hispanic women. Int. J. Epidemiol. 32, 150-156. doi: 10.1093/ije/ dyg024 
Palacios, N., Scott, T., Sahasrabudhe, N., Gao, X., and Tucker, K. L. (2019a). Lower plasma vitamin b-6 is associated with 2 -year cognitive decline in the boston puerto rican health study. J. Nutr. 149, 635-641. doi: 10.1093/jn/nxy268

Palacios, N., Scott, T., Sahasrabudhe, N., Gao, X., and Tucker, K. L. (2019b). Serum vitamin $\mathrm{d}$ and cognition in a cohort of boston-area puerto ricans. Nutr. Neurosci. 7, 1-8. doi: 10.1080/1028415x.2018.1545291

Pearson, K. E., Wadley, V. G., McClure, L. A., Shikany, J. M., Unverzagt, F. W., and Judd, S. E. (2016). Dietary patterns are associated with cognitive function in the reasons for geographic and racial differences in stroke (regards) cohort. J. Nutr. Sci. 5:e38.

Peña-Romero, A. C., Navas-Carrillo, D., Marín, F., and Orenes-Piñero, E. (2018). The future of nutrition: nutrigenomics and nutrigenetics in obesity and cardiovascular diseases. Crit. Rev. food Sci. Nutr. 58, 3030-3041. doi: 10.1080/ 10408398.2017.1349731

Powell, L. M., Slater, S., Mirtcheva, D., Bao, Y., and Chaloupka, F. J. (2007). Food store availability and neighborhood characteristics in the united states. Prev. Med. 44, 189-195. doi: 10.1016/j.ypmed.2006.08.008

Raffensperger, S., Kuczmarski, M. F., Hotchkiss, L., Cotugna, N., Evans, M. K., and Zonderman, A. B. (2010). Effect of race and predictors of socioeconomic status on diet quality in the handls study sample. J. Nat. Med. Assoc. 102, 923-930. doi: 10.1016/s0027-9684(15)30711-2

Reis, J. P., Selvin, E., Pankow, J. S., Michos, E. D., Rebholz, C. M., and Lutsey, P. L. (2016). Parathyroid hormone is associated with incident diabetes in white, but not black adults: the atherosclerosis risk in communities (aric) study. Diabetes Metab. 42, 162-169. doi: 10.1016/j.diabet.2015.12.004

Samieri, C., Morris, M. C., Bennett, D. A., Berr, C., Amouyel, P., Dartigues, J. F., et al. (2018). Fish intake, genetic predisposition to alzheimer disease, and decline in global cognition and memory in 5 cohorts of older persons. Am. J. Epidemiol. 187, 933-940. doi: 10.1093/aje/kwx330

Santoro, A., Bazzocchi, A., Guidarelli, G., Ostan, R., Giampieri, E., Mercatelli, D., et al. (2018). A cross-sectional analysis of body composition among healthy elderly from the european nu-age study: sex and country specific features. Front. Physiol. 9:1693. doi: 10.3389/fphys.2018.01693

Scarmeas, N., Stern, Y., Mayeux, R., Manly, J. J., Schupf, N., and Luchsinger, J. A. (2009). Mediterranean diet and mild cognitive impairment. Arch. Neurol. 66, 216-225.

Schneider, A. L. C., Zhao, D., Lutsey, P. L., Gottesman, R. F., Sharrett, A. R., Rawlings, A. M., et al. (2018). Serum vitamin d concentrations and cognitive change over 20 years: the atherosclerosis risk in communities neurocognitive study. Neuroepidemiology 51, 131-137. doi: 10.1159/000490912

Shukitt-Hale, B., Bielinski, D. F., Lau, F. C., Willis, L. M., Carey, A. N., and Joseph, J. A. (2015). The beneficial effects of berries on cognition, motor behaviour and neuronal function in ageing. Br. J. Nutr. 114, 1542-1549. doi: 10.1017/ s0007114515003451

Sucher, K. P., and Kittler, P. G. (2004). Food and Culture. Belmont, CA: Wadsworth.

Talegawkar, S. A., Johnson, E. J., Carithers, T. C., Taylor, H. A. Jr., Bogle, M. L., and Tucker, K. L. (2008). Serum carotenoid and tocopherol concentrations vary by dietary pattern among african americans. J. Am. Diet. Assoc. 108, 2013-2020. doi: 10.1016/j.jada.2008.09.004

Tangney, C. C., Kwasny, M. J., Li, H., Wilson, R. S., Evans, D. A., and Morris, M. C. (2011). Adherence to a mediterranean-type dietary pattern and cognitive decline in a community population. Am. J. Clin. Nutr. 93, 601-607. doi: 10. 3945/ajcn.110.007369

Tangney, C. C., Li, H., Wang, Y., Barnes, L., Schneider, J. A., Bennett, D. A., et al. (2014). Relation of dash- and mediterranean-like dietary patterns to cognitive decline in older persons. Neurology 83, 1410-1416. doi: 10.1212/wnl. 0000000000000884

Tangney, C. C., Tang, Y., Evans, D. A., and Morris, M. C. (2009). Biochemical indicators of vitamin b12 and folate insufficiency and cognitive decline. Neurology 72, 361-367. doi: 10.1212/01.wnl.0000341272.48617.b0

Thirumangalakudi, L., Prakasam, A., Zhang, R., Bimonte-Nelson, H., Sambamurti, K., Kindy, M. S., et al. (2008). High cholesterol-induced neuroinflammation and amyloid precursor protein processing correlate with loss of working memory in mice. J. Neurochem. 106, 475-485. doi: 10.1111/j.1471-4159.2008.05415.x

Townsend, M. S., Aaron, G. J., Monsivais, P., Keim, N. L., and Drewnowski, A. (2009). Less-energy-dense diets of low-income women in california are associated with higher energy-adjusted diet costs. Am. J. Clin. Nutr. 89, 12201226. doi: $10.3945 /$ ajcn.2008.26916

Travison, T. G., Chiu, G. R., McKinlay, J. B., and Araujo, A. B. (2011). Accounting for racial/ethnic variation in bone mineral content and density: the competing influences of socioeconomic factors, body composition, health and lifestyle, and circulating androgens and estrogens. Osteoporos. Int. 22, 2645-2654. doi: 10.1007/s00198-010-1520-y

Tsivgoulis, G., Judd, S., Letter, A. J., Alexandrov, A. V., Howard, G., Nahab, F., et al. (2013). Adherence to a mediterranean diet and risk of incident cognitive impairment. Neurology 80, 1684-1692. doi: 10.1212/wnl.0b013e3182904f69

Tucker, K. L., Bianchi, L. A., Maras, J., and Bermudez, O. I. (1998). Adaptation of a food frequency questionnaire to assess diets of puerto rican and non-hispanic adults. Am. J. Epidemiol. 148, 507-518. doi: 10.1093/oxfordjournals.aje.a00 9676

Tucker, K. L., Maras, J., Champagne, C., Connell, C., Goolsby, S., Weber, J., et al. (2007). A regional food-frequency questionnaire for the us mississippi delta. Public Health Nutr. 8, 87-96. doi: 10.1079/phn2005663

van de Rest, O., Wang, Y., Barnes, L. L., Tangney, C., Bennett, D. A., and Morris, M. C. (2016). Apoe e4 and the associations of seafood and long-chain omega-3 fatty acids with cognitive decline. Neurology 86, 2063-2070. doi: 10.1212/wnl. 0000000000002719

Watters, J. L., Satia, J. A., Kupper, L. L., Swenberg, J. A., Schroeder, J. C., and Switzer, B. R. (2007). Associations of antioxidant nutrients and oxidative dna damage in healthy african-american and white adults. Cancer Epidemiol. Biomarkers Prev. 16, 1428-1436. doi: 10.1158/1055-9965.epi-06-1030

Weuve, J., Barnes, L. L., Mendes de Leon, C. F., Rajan, K. B., Beck, T., Aggarwal, N. T., et al. (2018). Cognitive aging in black and white americans: cognition, cognitive decline, and incidence of alzheimer disease dementia. Epidemiology 29, 151-159. doi: 10.1097/ede.0000000000 000747

Willett, W. C. (2013). Implication of Total Energy Intake fo Epidemiological Analyses. Oxford: Oxford University Press.

Willett, W. C., Sampson, L., Stampfer, M. J., Rosner, B., Bain, C., Witschi, J., et al. (1985). Reproducibility and validity of a semiquantitative food frequency questionnaire. Am. J. Epidemiol. 122, 51-65.

Ye, X., Bhupathiraju, S. N., and Tucker, K. L. (2013a). Variety in fruit and vegetable intake and cognitive function in middle-aged and older puerto rican adults. Br. J. Nutr. 109, 503-510. doi: 10.1017/s00071145120 01183

Ye, X., Scott, T., Gao, X., Maras, J. E., Bakun, P. J., and Tucker, K. L. (2013b). Mediterranean diet, healthy eating index 2005, and cognitive function in middle-aged and older puerto rican adults. J. Acad. Nutr. Diet. 113, e1-e3.

Youdim, K. A., Dobbie, M. S., Kuhnle, G., Proteggente, A. R., Abbott, N. J., and Rice-Evans, C. (2003). Interaction between flavonoids and the blood-brain barrier: in vitro studies. J. Neurochem. 85, 180-192. doi: 10.1046/j.1471-4159. 2003.01652.x

Youdim, K. A., Qaiser, M. Z., Begley, D. J., Rice-Evans, C. A., and Abbott, N. J. (2004). Flavonoid permeability across an in situ model of the blood-brain barrier. Free Radic. Biol. Med. 36, 592-604. doi: 10.1016/j.freeradbiomed.2003. 11.023

Zuelsdorff, M., Okonkwo, O. C., Norton, D., Barnes, L. L., Graham, K. L., Clark, L. R., et al. (2020). Stressful life events and racial disparities in cognition among middle-aged and older adults. J. Alzheimers Dis. 73, 671-682. doi: 10.3233/jad190439

Conflict of Interest: The authors declare that the research was conducted in the absence of any commercial or financial relationships that could be construed as a potential conflict of interest.

Copyright (c) 2020 Agarwal, Morris and Barnes. This is an open-access article distributed under the terms of the Creative Commons Attribution License (CC BY). The use, distribution or reproduction in other forums is permitted, provided the original author(s) and the copyright owner(s) are credited and that the original publication in this journal is cited, in accordance with accepted academic practice. No use, distribution or reproduction is permitted which does not comply with these terms. 